\title{
A clinical sign of adenocystic tumour of the trachea
}

\author{
H. M. SINGH and D. M. E. THOMAS \\ Sully Hospital (Regional Cardiothoracic Unit for Wales), Nr. Cardiff
}

\begin{abstract}
Singh, H. M., and Thomas, D. M. E. (1973). Thorax, 28, 442-443. A clinical sign of adenocystic tumour of the trachea. Three patients with intrathoracic adenocystic tumour of the trachea presented as difficult diagnostic problems. All three patients had been labelled as psychiatric problems. Present in two of the cases, the sniff sign proved diagnostic and occurred at a stage when occlusion of the trachea during expiration was almost total. In order to breathe, the patients drew in small sharp, sniffing breaths. The sign owes its name to this pattern of breathing.
\end{abstract}

Adenocystic tumour of the trachea is rare. It ranks second to squamous-cell carcinoma in primary malignant tumours of the trachea. Salm (1964), reviewing 40 cases of primary carcinoma of the trachea in the preceding decade, noted $56 \%$ of these to be squamouscell carcinomata and $30 \%$ to be adenocystic tumours. Clark, Clagett, and McDonald (1953) described 15 patients and pointed out that surgery as against irradiation gave better results in the overall treatment of these patients. Zunker, Moore, Baker, and Lattes (1969) as well as Strobel (1966) attribute to irradiation a palliative value with temporary regression of the tumour.

The tumour is believed to grow slowly and to have high rates of invasiveness and recurrence,,$\frac{c}{<}$ and a definite but low potentiality for metastasis. $\vec{\varphi}$ Its slow growth makes it of all malignant tumours $\omega$ of the trachea the most amenable to surgery. Its invasiveness and late detection often contraindicateo such therapy.

We present three cases (Table I) with a clinicalo sign thought to be pathognomonic of slow growing intrathoracic intratracheal tumours. The sign has not previously been described in these tumours.

\section{DISCUSSION}

Ranke, Presley, and Holinger (1962) point out the difficulty of diagnosis in these patients and stress that a negative chest radiograph with hacking

T A B LE I

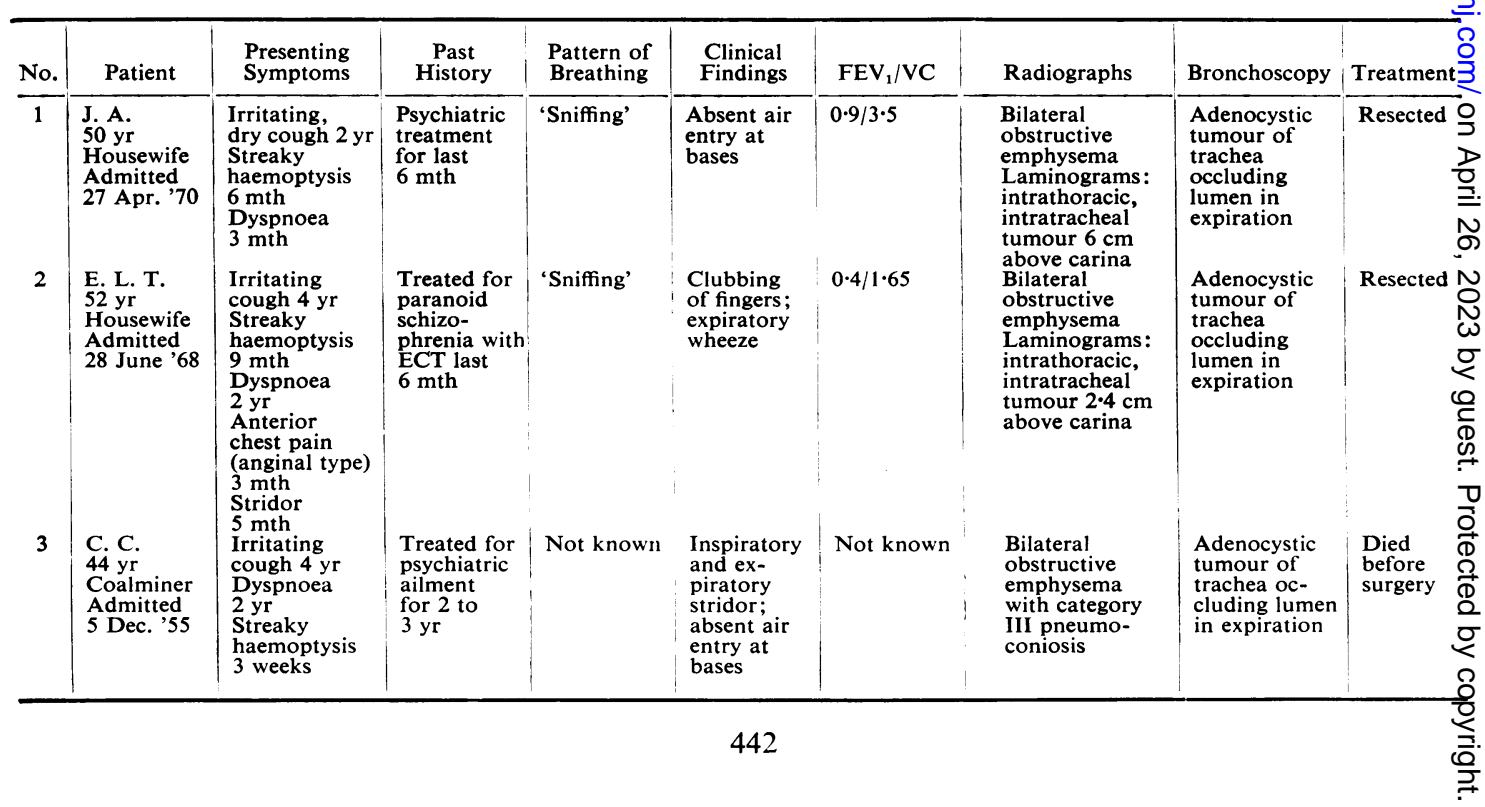


and irritating cough, wheeze, and blood-streaked sputum should be adequate for the diagnosis. However, they point out that some of the patients were treated by desensitizing procedures with various allergens before the diagnosis was made. Clark et al. (1953) stress that in the majority of their patients signs were present for two to four years before a diagnosis was made. As pointed out by Belsey (1950), signs of tracheal occlusion do not appear until the lumen has been narrowed by $75 \%$ or more. All three of our patients were remarkable in that they were considered to be suffering from psychiatric problems and had had several years of symptoms before a diagnosis was made.

The sign that we found characteristic of the lesion was present in the first of our two patients seen in recent years. It occurred at the stage when more than $75 \%$ of the tracheal lumen had been occluded. The patients presented with short, sharp, 'sniffing' inspirations as though 'afraid I might not be able to breathe all the air out'. Expiration at the end of a short sharp sniff seemed easier than if they had inspired a greater volume of air. The sign best described as the 'sniff sign' when associated with a wheeze is almost pathognomonic of tracheal occlusion. Bronchoscopic examination in the third patient also points to this phenomenon; the occlusion was found to be almost total in expiration but not so in inspiration. However, no note of the sign being present in this patient was recorded in 1955.

In retrospect three periods in the clinical evolution of a slow growing intrathoracic intratracheal tumour might be recognized (Table II).
T A B LE I I

\begin{tabular}{c|l|l|l|l}
\hline Stage & Lumen & \multicolumn{1}{|c|}{ Respiration } & Symptoms/Signs & Duration \\
\hline I & $\begin{array}{l}\text { Less than } \\
75 \% \text { lumen } \\
\text { Occlusion }\end{array}$ & $\begin{array}{l}\text { Inspiration and } \\
\text { expiration both } \\
\text { normal }\end{array}$ & $\begin{array}{l}\text { Tracheal irr- } \\
\text { itation; } \\
\text { hacking cough; } \\
\text { bloodstreaked } \\
\text { sputum }\end{array}$ & $\begin{array}{l}2 \text { to 4 } \\
\text { yr or } \\
\text { more }\end{array}$ \\
\hline II & $\begin{array}{l}75 \% \text { lumen } \\
\text { Occlusion }\end{array}$ & $\begin{array}{l}\text { Expiration grad- } \\
\text { ually more diff- } \\
\text { icult; inspirat- } \\
\text { ion normal or } \\
\text { mildly affected }\end{array}$ & $\begin{array}{l}\text { Shortness of } \\
\text { breath; } \\
\text { wheeze +; } \\
\text { bloodstreaked } \\
\text { sputum }\end{array}$ & $\begin{array}{l}\text { Few } \\
\text { months } \\
\text { to 2 yr } \\
\text { or more }\end{array}$ \\
\hline III & $\begin{array}{l}\text { Further } \\
\text { Occlusion }\end{array}$ & $\begin{array}{l}\text { Expiration more } \\
\text { severely limited; } \\
\text { inspiration } \\
\text { shorter and } \\
\text { sharper; } \\
\text { sniffing }\end{array}$ & $\begin{array}{l}\text { Shortness of } \\
\text { breath more } \\
\text { marked; } \\
\text { wheeze + + } \\
\text { sniff sign + } \\
\text { x-ray obstruc- } \\
\text { tive emphysema }\end{array}$ & $\begin{array}{l}\text { Few } \\
\text { weeks to } \\
\text { few } \\
\text { months }\end{array}$ \\
\hline
\end{tabular}

Although the sign is a late occurrence, it represents a physiological adaptation in the pattern of breathing and should point to the diagnosis.

\section{REFERENCES}

Belsey, R. (1950). Resection and reconstruction of intrathoracic trachea. British Journal of Surgery, 38, 200.

Clark, P. L., Clagett, O. T., and McDonald, J. R. (1953). Cylindromas of the trachea. Proceedings of the Staff Meetings of the Mayo Clinic, 28, 513.

Ranke, E. J., Presley, S. S., and Hollinger, P. H. (1962). Tracheogenic carcinoma. Journal of the American Medical Association, 182, 519.

Salm, R. (1964). Primary carcinoma of the trachea. British Journal of Diseases of the Chest, 58, 61.

Strobel, H. (1966). Zur Prognose der Zylindrome. Zeitschrift für Laryngologie, Rhinologie, Otologie und ihre Grenzgebiete, 45, 33.

Zunker, H. O., Moore, R. L., Baker, D. C., and Lattes, R. (1969). Adenoid cystic carcinoma (cylindroma of the trachea). Cancer, 23, 699. 